\title{
Digital Technologies in the Context of the Implementation of the Responsibility by Government Officials
}

\author{
Azat Albertovich Gafurov ${ }^{1}$, Aleksandr Fedorovich Malyj $^{2}$, Ella Rolandovna Adamova ${ }^{3}$ \\ ${ }^{1}$ Applicant, Department of Constitutional and Administrative Law, Kazan Federal University, \\ Orcid 0000-0002-3865-9869, \\ ${ }^{2}$ Doctor of Law, Professor of the Department of Constitutional and Administrative Law, Kazan Federal University, \\ Orcid 0000-0002-9983-4894, \\ ${ }^{3}$ Lecturer, Department of Constitutional and Administrative Law, Kazan Federal University, \\ Orcid 0000-0001-7579-8932,
}

\begin{abstract}
The study is devoted to one of the topical areas of modern jurisprudence, i.e. digital technologies in law. The authors made an attempt to reveal the use of digital technologies in the context of the implementation of the responsibility by government officials. The paper examines Russian and foreign studies regarding both digital technologies in law and the institution of responsibility held by officials from public authorities. The authors reveal their features, substantiate the effectiveness and constructiveness of their application in the implementation of the responsibility held by officials from executive authorities based on analysis of the studies by the example of the legislation of the Russian Federation and foreign countries, and the practice of using digital technologies. In addition, the authors conduct a comparative legal analysis of their legal regulation and focus on possible problematic aspects. The conclusion is made that on the basis of the existing constitutional practice and the rapid development of digital technologies, it is necessary to change a number of normative legal acts that ensure their use.
\end{abstract}

Key words: digital law, digital technologies, officials, executive authorities, responsibility.

\section{INTRODUCTION}

Digital law is a relatively recent area of modern legal science. It is becoming more and more relevant in connection with the development of digital technologies and the daily use of its capabilities in various spheres of the state and society. One of these areas is the responsibility of public officials.

The responsibility of officials of public authorities is one of the necessary elements of state constitutional system and a legal guarantee of the application of constitutional norms and their observance. However, along with the legislative expression of that responsibility, one should consider the implementation of the action of the responsibility mechanism by using the possibilities of technological progress and digital informatisation of the state and society. With regard to their activities, it seems relevant to design an effective mechanism for implementing responsibility using the capabilities of digital technologies, which can significantly improve the quality of law enforcement in public authorities.
However, due to the dynamic development of digital technologies, Russian and foreign scientists cannot clearly determine the subject of digital law regulation; they also find it difficult to define the scope it covers. Therefore, improving the regulatory and practical implementation of the responsibility of government officials using the latest technologies and practices is an urgent task of both Russian and foreign law.

\section{METHODS}

The methodological basis of the research is represented by a system of general scientific and specific scientific methods of cognition, which made it possible to most objectively consider the subject of research from the standpoint of its internal logic. The use of dialectical and systemic-structural methods made it possible to analyse and generalize ideas of Russian and foreign scientists about digital law and, on their basis, to build a concept of the possibility of using digital technologies in the responsibility of government officials. The methods of theoretical and prognostic methods, legal modelling and comparative legal plan were used as private law methods. A comparison of various points of view regarding digital law and responsibility was carried out with their help; it was possible to analyse the norms of legislation both in the Russian Federation and foreign states in these areas. We have used such general logical methods of cognition as deduction and induction, which contributed to the creation of an optimal research concept; analysis and synthesis, which made it possible to comprehensively and in an integrated manner to investigate the essence and structure of responsibility held by officials of public authorities. The study was carried out in accordance with the requirements of the principle of unity in the logical cognition of the essence and system of state power.

\section{RESULTS AND DISCUSSION}

Digital technologies have a significant impact on all spheres of public relations, which are traditionally subject to legal regulation. The development of information technology and the widespread use of its capabilities have spawned their own sphere of law, the so-called digital law. American scholar Robert J. Ambrogi rightly points out that digital law is "a 
dynamic, flexible and unexplored area of practice, where the rules are not finitely defined yet. In fact, this is not even a separate area of law, in fact it is a mixture of theory and practice taken from various spheres of social relations" [1].

Foreign scholars note that, unlike all other branches of law, digital law is not a specific, stable and reliable area of practice and it encompasses principles and rules from a number of different branches [2]. Moreover, digital law was initially considered in foreign jurisprudence not as an independent branch of law, but as a kind of set of multidirectional legal norms and institutions related to various branches (areas) of law and regulating relations that are somehow connected with digital technologies, in particular with the Internet network. [3]. In this regard, the foreign literature reveals a multidimensional content devoted to the problems of digital law. So, along with the term "digital law", the terms "cyber law", "cyberspace law", "web law", "computer law" and others are used, which were disclosed not as independent branches of law, but as a set of diverse legal norms and institutions, related to various branches (areas) of law, the association of which is carried out in each case in accordance with subjective criteria and tasks set $[4,5]$.

One way or another, digital law is based on traditional legal institutions that, in general, do not change under the influence of digital technologies. However, they need to maintain some additional normative legal acts, norms or interpretations (for example, the use of a digital signature, holding court sessions online, etc.) regulating the use of digital technologies. The development and improvement of legal institutions and regulations (in particular, legislation on information security, online petitions, social networks, instant messengers, telecommunications, etc.) is most associated with the development of the Internet network. Therefore, in relation to traditional legislation, it will be successful to use a predictive approach to create the basis for the application of digital technologies in law. Meanwhile, fundamentally new relations associated with the Internet network, undoubtedly, require the development of new legislation in full compliance with legal techniques.

Undoubtedly, digital technologies currently significantly affect the legal sphere and are an effective tool to stimulate its development. In these conditions, the "law of information technology" (Information Technology Law, abbreviated - IP Law, Technology Law, Tech Law) has developed. However, it is viewed not as an independent branch of law, but as a set of diversified legal norms and institutions that regulate relations associated with the use of various information technologies [11].

Modern information technologies are subdivided into analogue and digital according to the method of their information presentation. Moreover, digital technologies are not only in more demand than analogue ones due to a number of advantages, but today it is recognized that it is digital technologies that shape the economy [12]. In particular, artificial intelligence, big data analytics, distributed ledger technology, including blockchain, cryptocurrency, the virtual reality, augmented reality, 5G, and cloud computing are classified among the iconic digital technologies today. Since law is an immanent part of the economy, it is natural to conclude that the development, implementation and use of digital technologies will have a serious impact on the law, affecting most industries.

Domestic legal science is also aimed at solving problems associated with the possibilities of using digital technologies in the legal sphere: finding an optimal solution and developing models of legal regulation of public relations, which are consolidated with the "digitalization" of technologies in the field of finance, public administration, the creation of artificial intelligence, etc. [7, 8]. Thus, digital solutions are increasingly being used in various types of legal activities (judicial, law enforcement, and human right activity, etc.). Thus, the Russian legal system becomes an object of digitalization, as a result of which it undergoes changes in its form, content, system, structure and mechanism of action. New technical solutions and innovations are aimed not only at providing convenience and reducing financial costs, but also at increasing transparency in the activities of participants in legal relations.

Since the active introduction of digital technologies, their advantages have been used in the activities of state bodies and officials. On the basis of the Federal Law dated February 9, 2009 No. 8-FZ "On ensuring access to information on the activities of state bodies and local self-government bodies" [9], a unified procedure for access of citizens and organizations to information on the activities of state bodies and local self-government bodies is established. One of the ways to provide access to such information is the Internet network, where the main means of publishing information on the activities of state bodies and local self-government bodies are their official sites. Currently, the electronic system of official Internet network resources of both state and municipal authorities is actively developing. For example, there is a single server of the government authorities of the Russian Federation (www.gov.ru), where government bodies are registered in each domain. For example, the official website of the President of the Russian Federation is kremlin.ru, the State Duma - duma.gov.ru, the Government of the Russian Federation - government.ru.

To solve individual problems, unified state reference and information resources are being created. For example, the federal portal of civil service and managerial personnel gossluzhba.gov.ru is being developed on the basis of the Decree of the Government of the Russian Federation dated June 17, 2015 No. 602 "On some measures to improve informatisation in the field of staffing of state bodies and local self-government bodies" [10]. A single portal of the budgetary system of the Russian Federation budget.gov.ru functions on the basis of the Decree by the Government of the Russian Federation dated June 30, 2015 No. 658 "On the state integrated information system for managing public finances "Electronic budget" [13]. The functioning of a single portal of state and municipal services gosuslugi.ru is carried out in accordance with the Federal Law dated July 27, 2010 No. $210-\mathrm{FZ}$ "On the organization of the provision of state and municipal services" [14]. 
Moreover, it became possible to identify illegal behaviour of officials and respond to them in a timely manner with the help of digital technologies. For example, an electronic register has created gossluzhba.gov.ru/reestr to improve the efficiency of anti-corruption legislation and fight unscrupulous officials; it contains data on persons dismissed due to loss of confidence for committing a corruption offense [15]. On the one hand, this register keeps records of persons who have committed an offense and contains legal consequences for their further employment; on the other hand, due to its openness and publicity, it contributes to the lawful behaviour of officials.

Thus, a promising idea for improving the mechanism for implementing the responsibility of government officials is to use the advantages of digital technologies. It seems that the implementation of this idea is possible through mechanisms that will provide better feedback both with the instances of applying responsibility and with the population. This will help to form a better quality description of their activities and will minimize the corruption component, irrationality and abuse of office.

\section{SUMMARY}

1. Digital law should be understood as a set of legal norms and institutions that regulate various relations associated with the introduction and use of digital technologies, but these norms are not united by a single regulation method and relate to various branches of law. Moreover, digital law is a dynamically expanding legal entity;

2. Digital technologies not only stimulate an increase in the efficiency of the activities of officials and the exercise of their powers, but also allow them to respond in a timely manner to inappropriate behaviour. Digital technologies ensure interaction based on accessibility and timeliness, and thereby implement the following principles of the activities of public officials:

- Ensuring transparency of goals, actions and efficiency of performance management;

- Compliance of the tasks solved by officials of all levels of government with the strategic goals of the state;

- Unlocking the potential of officials for the highquality implementation of their functions and powers;

- The use of tools for comprehensive online monitoring of the activities of government officials and the quality of their performance of tasks.

\section{CONCLUSIONS}

With the advent of digital technologies, society has obtained an opportunity to influence officials through public events, appeals regarding illegal actions or inaction (both in the form of individual appeal and in the form of petitions). Officials will be forced to perform their duties more conscientiously, efficiently and lawfully if there is feedback and real-time control over the process and the results of their activities by the authorities of responsibility. Therefore, the implementation of the responsibility held by officials of public authorities using digital technologies and the Internet network contributes to a more efficient and high-quality performance of their official duties and adherence to the established rules of law.

\section{ACKNOWLEDGEMENTS}

The work is performed according to the Russian Government Program of Competitive Growth of Kazan Federal University.

\section{REFERENCES}

[1] Ambrogi, Robert J. The Essential Guide to the Best (and Worst) Legal Sites on the Web. 2th edn. N.Y.: ALM Publishing, 2004: P. 139 (Chapter 12).

[2] DiGiacomo J. Internet network Law: Everything You Need To Know. June 7, 2019. // URL: https://revisionlegal.com/Internet network-law/Internet network-law-everything-you-need-to-know/

[3] Rozhkova MA. Is digital law a branch of law and should we expect the emergence of a Digital Code? Economy and law. 2020; 4: 3-13.

[4] Graham JH. Smith. Internet network Law and Regulation (Special Report). Fourth Edition. London: Sweet \& Maxwell. 2007.

[5] Grimmelmann, James. Internet network Law: Cases \& Problems. $7^{\text {th }}$ edn. 2017.

[6] Raysman R, Brown P. Computer Law: Drafting and Negotiating Forms and Agreements. Law Journal Press; 1984.

[7] Radchenko MYu, Gorbunov VP. Digital law of the future. II All-Russian conference "Law and the Internet: theory and practice" (28-29 November, 2000, Russia, Moscow). Reports. URL: http://www.ifap.ru/pi/02/r09.htm;

[8] Tereshchenko LK. Modernization of information relations and information legislation: monograph. M., 2013.

[9] Federal Law of the Russian Federation dated February 9, 2009 No. 8-FZ "On ensuring access to information on the activities of state bodies and local self-government bodies" // Rossiyskaya Gazeta, dated February 13, 2009 No. 25.

[10] Decree of the Government of the Russian Federation dated June 17, 2015 No. 602 "On some measures to improve informatisation in the field of staffing of state bodies and local governments" // Collected Legislation of the Russian Federation, 06/29/2015, No. 26. Art. 3896.

[11] Lloyd I. Information Technology Law. $6^{\text {th }}$ edn. Oxford University Press, 2011. 
International Journal of Engineering Research and Technology. ISSN 0974-3154, Volume 13, Number 11 (2020), pp. 3475-3478

(C) International Research Publication House. https://dx.doi.org/10.37624/IJERT/13.11.2020.3475-3478

[12] Levin VO. History of information technology. 2007; P.11.

[13] Decree of the Government of the Russian Federation dated June 30, 2015 No. 658 "On the state integrated information system for public finance management" Electronic budget "// Collected Legislation of the Russian Federation dated July 13, 2015 No. 28. Art. 4228.

[14] Federal Law of the Russian Federation dated July 27, 2010 No. 210-FZ "On the organization of the provision of state and municipal services" // Rossiyskaya Gazeta, No. 168. 30.07.2010.

[15] Resolution of the Government of the Russian Federation dated March 5, 2018 No. 228 "On the register of persons dismissed due to loss of confidence" // Collected Legislation of the Russian Federation, 03/19/2018, No. 12. Art. 1678. 